Дергачова B.B.

доктор економ. наук, професор ORCID ID: 0000-0003-0317-8675

Островерха Д.В. ORCID ID: 0000-0002-6972-1231

Національний технічний університет Украӥни «Київький політехнічний інститут імені Ігоря Сікорського»

\title{
РОЛЬ ТА ЗНАЧЕННЯ МІЖНАРОДНОГО АУТСОРСИНГУ: ЗАРУБІЖНИЙ ДОСВІД ТА ПЕРСПЕКТИВИ ЙОГО ВПРОВАДЖЕННЯ В УКРАЇ̈I
}

\section{РОЛЬ И ЗНАЧЕНИЕ МЕЖДУНАРОДНОГО АУТСОРСИНГА: ЗАРУБЕЖНЫЙ ОПЫТ И ПЕРСПЕКТИВЫ ЕГО ОСУЩЕСТВЛЕНИЯ В УКРАИНЕ}

\section{ROLE AND IMPORTANCE OF INTERNATIONAL OUTSOURCING: FOREIGN EXPERIENCE AND PROSPECTS OF ITS IMPLEMENTATION IN UKRAINE}

У статті розглядаються роль та значення міжнародного аутсорсингу для зарубіжних компаній та можливі напрямки його впровадження на вітчизняних підприсмствах, спираючись на досвід закордонних партнерів, а саме було розглянуто сутність поняття «аутсорсинг» та його види, виокремлено особливості виникнення аутсорсингу і його подальшого розвитку у різних краӥнах світу, зазначено характерні риси американської та японської моделей побудови відносин на рівні «замовник постачальник». Також було розглянуло сучасний стан застосування аутсорсингу в Украӥні: рейтинг держави відповідно до іниих краӥн, видові особливості,географічну структуру та регулювання даної діяльності вітчизняним законодавством. 3 огляду на проведене дослідження було проведено порівняльний аналіз використання практики аутсорсингу в різних країнах світу та Украӥни, щчо довів існування як спільних рис, так $i$ відмінностей кожного регіону, що свідчать про існування впливу факторів зовнішнього середовища у межах кожної країни: економічної ситуації в ијілому, структури економіки, бізнес-культури, тошо. діяльність.

Ключові слова: аутсорсинг, міжнародний аутсорсинг, зовнішньоекономічна

В статье рассматриваются роль и значение международного аутсорсинга для зарубежных компаний и возможные направления его внедрения на отечественных предприятиях, опираясь на опыт зарубежных партнеров, а именно были рассмотрены суть понятия «аутсорсинг» и его виды, выделены особенности возникновения аутсорсинга и его дальнейшего развития в разных странах мира, говорится характерные черты американской и японской моделей построения отношений на уровне «заказчик поставщик». Также было рассмотрело современное состояние применения аутсорсинга в Украине: рейтинг государства в соответствии с других стран, видовые особенности, географическую структуру и регулирования данной деятельности отечественным законодательством. Учитывая проведенное исследование было проведено сравнительный анализ использования практики аутсорсинга в различных странах мира и Украины, 
доказавший существование как общих черт, так и различий каждого региона, свидетельствуют о существовании влияния факторов внешней среды в пределах каждой страны: экономической ситуации в иеелом, структуры экономики, бизнес-культуры, и т. $n$.

Ключевые слова: аутсорсинг, международный аутсорсинг, внешнеэкономическая деятельность.

The article presents the role and importance of international outsourcing for foreign companies and possible ways of its implementation in domestic enterprises, relying on the experience of foreign partners and is considered the essence of the concept of «outsourcing» and its species singled out the features of the emergence of outsourcing and its future development in different countries world, described the characteristics of American and Japanese models build relationships at "customer - supplier». It was also considered the current state of the use of outsourcing in Ukraine according to the rating of the state of other countries, specific characteristics, geographical structure and regulation of the activities of domestic law. In view of this study was a comparative analysis of the use of the practice of outsourcing in different countries and Ukraine, which proved the existence of both similarities and differences in each region, as evidenced by the existence of the influence of environmental factors within each country: the economic situation in general, economic structure, business culture, and so on.

Keywords: outsourcing, international outsourcing, foreign trade.

Вступ. Застосування аутсорсингу $\epsilon$ необхідним заходом для підприємств, що мають на меті суттєво підвищити конкурентоспроможність за рахунок використання нових технологій, реструктуризації менеджменту та оптимізації виробничих процесів. Світовий досвід підтверджує, що переваги аутсорсингу $є$ невід'ємною частиною успішних підприємств, оскільки забезпечують високий рівень конкурентоспроможності зарубіжних компаній на міжнародному ринку. Саме тому особливої актуальності набуває дослідження ролі та значення зарубіжного досвіду використання міжнародного аутсорсингу з метою його впровадження і вдосконалення на підприємствах України.

Щодо характеристики наукових досліджень у сфері аутсорсингу, то він може бути розглянутий 3 точки зору двох напрямів: аутсорсинг як взаємовідносини «замовник-постачальник» та аутсорсинг як інструмент управління сучасним підприємством.

Дослідження у сфері міжнародного досвіду та вітчизняної практики застосування аутсорсингу провели Нагорна О. [2], Сівачова О. [4], Кулиняк I. [6] та Маленко О. [9]. Особливості аутсорсингу в Україні мають місце у працях Красношапки В. [1], Ковальчук Г. [5] та Мінченко О. [11].

Постановка завдання. Метою даного дослідження $\epsilon$ аналіз зарубіжного досвіду використання міжнародного аутсорсингу з метою застосування його практики на вітчизняних підприємствах. Для цього необхідним $є$ виконання наступних завдань: розгляд теоретичних основ міжнародного аутсорсингу, визначення пріоритетних напрямків розвитку зарубіжних підприємств у сфері 
аутсорсингу та виявлення перспектив їх впровадження для підприємств України.

Методологія. При написанні даної роботи було використано графічний метод (для наочного представлення результатів дослідження), табличний, метод узагальнення та систематизація, метод порівняння (для співставлення результатів дослідження), а також інші методи загальнонаукового характеру.

Результати дослідження. В умовах глобалізації, компанії для підвищення власної конкурентоспроможності на ринку та зниження витрат на виробничі процеси, все частіше передають другорядні задачі в діяльності організації до послуг зовнішніх підрядчиків - спеціалізованих агентств, в розпорядженні яких $\epsilon$ висококваліфіковані кадри. Зазначена практика має назву аутсорсинг. Сутність аутсорсингу в загальному вигляді полягає у тому, що організація отримує можливість розставити пріоритети у своїй діяльності та зосередитись на тій іiі складовій, яка є основною, визначальною та найбільш важливою, а інші другорядні, або технічні, функції передаються професійним партнерам [1]. Мотиви та користь від укладення аутсорсингових договорів наведено в табл. 1.

Таблиця 1

Мотиви та користь від укладення аутсорсингових договорів

\begin{tabular}{|c|c|}
\hline Назва & Характеристика \\
\hline Мотиви & $\begin{array}{ll}- & \text { скорочення та контроль витрат виробництва; } \\
- & \text { доступ до світових виробничих технологій; } \\
- & \text { відсутність на підприємствах необхідного обладнання, знань та } \\
& \text { технологій; } \\
- & \text { залучення висококваліфікованих спеціалістів; }\end{array}$ \\
\hline Користь & $\begin{array}{ll}- & \text { велика гнучкість та швидка адаптація до змін попиту; } \\
- & \text { оптимізація виробничого процесу; } \\
- & \text { розподіл виробничого процесу між спеціалізованими } \\
& \text { підприємствами - аутсорсерами,; } \\
- & \text { суттєве посилення конкурентоспроможності. }\end{array}$ \\
\hline
\end{tabular}

Джерело: [2]

Тим не менш, на противагу значним перевагам бізнес-моделі міжнародного аутсорсингу виступає цілий ряд ризиків. У більшості випадків ризики пов'язані 3 можливими проблемами при укладанні контрактів і підписанні договорів, оскільки такого роду договори повинні бути взаємовигідними та враховувати можливі зміни в потребах партнерів. Крім того, в багатьох випадках цілком імовірно, що компанія-партнер може стати конкурентом, змінивши галузь спеціалізації або використовуючи більш досконалу організаційну політику та технологічні ноу-хау, щоб здобути конкурентні переваги та увійти в відповідний ринок [3]. 
Виділяють декілька видів аутсорсингу. Характерні відмінності сутності понять «офшоринг», «аутсорсинг» та «офшорний аутсорсинг» наведені в табл. 2.

Характерні відмінності сутності понять «офшоринг», «аутсорсинг»та «офшорний аутсорсинг»

\begin{tabular}{|c|c|c|c|}
\hline \multirow{2}{*}{ Категорії } & \multicolumn{3}{|c|}{ Види аутсорсингу } \\
\hline & Офшоринг & Аутсорсинг & Офшорний аутсорсинг \\
\hline $\begin{array}{l}\text { Місце } \\
\text { розташування } \\
\text { постачальника і } \\
\text { замовника }\end{array}$ & $\begin{array}{l}\text { замовник і компанія } \\
\text { субпідряд } \\
\text { перебувають на } \\
\text { території різних } \\
\text { країн }\end{array}$ & $\begin{array}{l}\text { замовник і } \\
\text { аутсорсер } \\
\text { перебувають у } \\
\text { межах однієї } \\
\text { країни }\end{array}$ & $\begin{array}{l}\text { замовник і аутсорсер } \\
\text { перебувають у різних } \\
\text { країнах }\end{array}$ \\
\hline $\begin{array}{l}\text { Підпорядкування } \\
\text { постачальника і } \\
\text { замовника }\end{array}$ & $\begin{array}{l}\epsilon \text { підрозділом } \\
\text { замовника }\end{array}$ & $\begin{array}{l}\epsilon \text { незалежним } \\
\text { підприємством }\end{array}$ & $\begin{array}{l}\epsilon \text { незалежним } \\
\text { підприємством }\end{array}$ \\
\hline
\end{tabular}

Виникнення інструменту аутсорсингу пов'язують 3 автомобільним бізнесом, зокрема компанією General Motors та іï діяльністю в 70-х роках $\mathrm{XX}$ ст. Керівництво почало серію змін на підприємстві, які базувалися на висновку Г.Форда, що спеціалізовані фірми виконують свої функції краще, ніж його власні підрозділи. Компанія Toyota, використовуючи виробничий аутсорсинг, що передбачає передачу частини ланцюжка виробничих процесів або цілком весь цикл виробництва сторонній організації, сьогодні займається фактично тільки проектуванням, складанням і реалізацією продукції, а більша частина деталей і комплектуючих виробляється іншими, найчастіше великими підприємствами. Такий спосіб ведення бізнесу характерний для майже всіх японських виробників автомобілів.

Журнал Fortune затверджує, що як мінімум 90\% сучасних підприємств використовують аутсорсинг хоча б одного бізнес-процесу. Toyota, Honda, Chrysler делегують стороннім підрядникам приблизно 70\% бізнес-процесів. Значних успіхів у використанні аутсорсингу досягли японські компанії, які розробили і широко застосовують логістичну систему постачання «Just-inTime», при якій зовнішній постачальник доставляє до замовника комплектуючі за чітким графіком, а одержувачу навіть немає необхідності створювати у себе їх резервний склад [5].

Світовий досвід дає можливість побачити доцільність використання аутсорсингу на підприємстві, а саме: підвищення гнучкості виробництва, зниження загальних витрат, зменшення адміністративних витрат $i$, як наслідок, підвищення конкурентоспроможності підприємства, адже аутсорсинг став одним 3 елементів, що забезпечили високі темпи економічного розвитку в таких країнах, як Японія, США, Німеччина, Франція, Італія, Іспанія, Туреччина [6]. 
ISG Information Services Group надає щорічно статистику кількості i вартості аутсорсингових контрактів у світі (враховуються контракти, річна вартість яких не менше 5 млн дол). 5 серпня 2015 року аналітична i консалтингова компанія Information Services Group (ISG) оприлюднила результати дослідження ринку аутсорсингу в регіоні EMEA за підсумками другого кварталу i першого півріччя. Із звіту також випливає, що за підсумками перших шести місяців 2015 року обсяг ринку аутсорсингу бізнеспроцесів на території ЕМЕА залишився на рівні попереднього року і склав 900 млн євро. Вартість контрактів в області IT-аутсорсингу знизилася на чверть до 3,2 млрд євро, в той час як в попередні роки цей сегмент показував піврічний обсяг на рівні 4,3 млрд євро. Найпривабливішим ринком аутсорсингу аналітики називають британський, який у другій чверті 2015 року збільшився на $150 \%$ в грошовому еквіваленті. У Східній Європі зафіксоване невелике зростання як у вартісному вираженні, так і в кількості контрактів, однак цей субрегіон за мірками всього ЕМЕА характеризується невеликим розміром продажів аутсорсингових послуг.

Як повідомили аналітики 31 серпня 2015 року, в наступні 36 місяців завершиться час дії аутсорсингових угод загальною вартістю 250 млрд. дол. Хоча американські гіганти IBM і НР, швидше за все, збережуть партнерські зв'язки 3 діючими клієнтами, індійські конкуренти продовжують активно нарощувати свою ринкову частку. За даними ISG за першу половину 2015 року, під контролем компаній 3 Індії знаходиться $27,1 \%$ світового ринку аутсорсингу проти $23,6 \%$ роком раніше. Вони змогли зміцнити позиції за рахунок невдач європейських конкурентів, таких як Capgemini i Atos, кажуть фахівці. Індійські IT-фірми, такі як Tata Consultancy Services i Infosys, націлені на великі контракти і для залучення кліснтів використовують більш вигідне для замовників ціноутворення, а також пропонують їм працювати без великих авансових платежів [7].

За різними підрахунками, у США послугами професійних підрядників користуються близько $60 \%$ підприємств, у Європі - близько 45\%. За результатами дослідження Yankelovich Partners, проведеного в 14 країнах світу, 63\% опитаних підтвердили, що вони передали в управління підрядникам одну або кілька непрофільних функцій. 3 тих, хто здійснив аутсорсинг, 84\% були налаштовані позитивно і стверджували, що задоволені роботою аутсорсингових компаній [8].

Важливим аспектом аутсорсингової діяльності $є$ побудова відносин на рівні «замовник - постачальник». На сьогодні експерти виділяють дві моделі, які в літературі одержали назву американської (горизонтальної) i японської (пірамідальної).

Перша спрямована на використання послуг великої кількості постачальників та лише в межах одного замовлення, в той час як інша розрахована на довгострокову перспективу. Японська модель дозволяє 
сформувати галузеві та міжгалузеві кластери, що є іiі безсумнівною перевагою перед американською моделлю, яка цілком могла стати однією 3 причин зниження економічного ефекту використання аутсорсингу у межах всієї країни.

До основних країн перебування належать Індія, Китай, Східна Європа, Філіппіни, Панама, Ірландія, Єгипет і деякі інші, що володіють такими властивостями, як:

- наявність великого обсягу кваліфікованої робочої сили;

- $\quad$ низькооплачувана праця;

- $\quad$ висока якість освіти;

- $\quad$ знання іноземних мов;

- висока мотивація співробітників (для яких робота в компанії означає можливість працювати за спеціальністю й значне кар'єрне зростання);

- $\quad$ поліпшення в телекомунікаційній структурі.

При цьому в кожної країни, безумовно, $є$ свої переваги й недоліки. Так, наприклад, в Індії добре володіють англійською мовою, тоді як у Східній Європі й Китаї знання мови на порядок гірше. В Україні $\epsilon$ багато висококваліфікованих програмістів, але нестабільна політична ситуація може негативно позначитися на роботі компаній. Між тим становище в країні перебування може змінюватися.

Лідер аутсорсингу - Індія. На іiі частку припадає 50-80\% доходів від аутсорсингу в усьому світі. Успіх індійських компаній багато в чому пояснюється грамотною політикою держави. Саме індійська влада наприкінці 1980-х pр., коли країна ще була закрита для закордонних компаній, визначала напрямки розвитку галузі інформаційних технологій. Це відбувалося за рахунок того, що держава була єдиним замовником високотехнологічної продукції, зробленої в Індії [9].

Отже, міжнародний аутсорсинг набуває неабиякого значення для міжнародного бізнесу. Він сприяе зменшенню витрат, а тим самим i зменшенню ціни кінцевої продукції. Україна на сучасному ринку аутсорсингу виступає постачальником аутсорсингових послуг, що створює передумови переходу українських підприємств на інноваційний шлях розвитку [8].

За останньою статистикою, опублікованою IT Outsoursing News, майже 100 тис. українських програмістів задіяні на світовому ринку, а до 2020 року їх буде не менше 200 тис. Це найбільший показник у Європі. Понад 100 високотехнологічних транснаціональних компаній активно залучають технарів з України. Cisco, Oracle, Rakuten, Samsung шукають тут виконавців, а локальні компанії аутсорсингу допомагають сформувати команду висококваліфікованих фрілансерів й розвивають сектор R\&D (Research and Development). Українські розробники працюють у корпоративних і веб-проектах на різних вертикалях, частина провайдерів побудували свою репутацію на вирішенні складних 
інженерних завдань. У 2015 року з України було експортовано програмне забезпечення на суму 2,5 млрд дол. Це лише частина потенціалу країни, зазначають у дослідженні, зважаючи на велику кількість кваліфікованих фахівців і їхню зацікавленість у включенні до сектору R\&D.

Найбільше українські аутсорсери працюють з США - на цю країну припадає близько 80\% експорту IT-послуг. За ними йдуть країни Євросоюзу та Ізраїль. Серед конкурентних переваг України - широкий спектр технічних можливостей, від програмного забезпечення до промислової інженерії. Успіх українських розробників на міжнародних технологічних виставках також піднімає рейтинг країни. Більше половини центрів R\&D сконцентровані в Києві. Також ключові міста для такої діяльності - Дніпропетровськ, Львів, Одеса, Харків і Вінниця [10].

Проте, аутсорсинг в Україні стикається з певними проблемами його застосування. Однієї із основних перешкод на шляху активного впровадження аутсорсингу на теренах України $є$ відсутність визначення процесів аутсорсингу та їх нормативно-правового регулювання, контролю та відповідальності за порушення. Саме поняття «аутсорсинг» в українському праві не має дефініції, тому може регулюватись виключно у контексті аналогії до деяких правових норм. У той же час у законодавчому полі визначено економічну взаємодію через укладання договорів, а також те, що кожен має право займатись підприємницькою діяльністю, яка не заборонена законом. Тож, дані положення лише доводять невизначеність та неефективність українського законодавства щодо надання та отримання послуг аутсорсингу.

Крім того, аутсорсинг в Україні має свої особливості щодо популярності окремих його видів (рисунок).

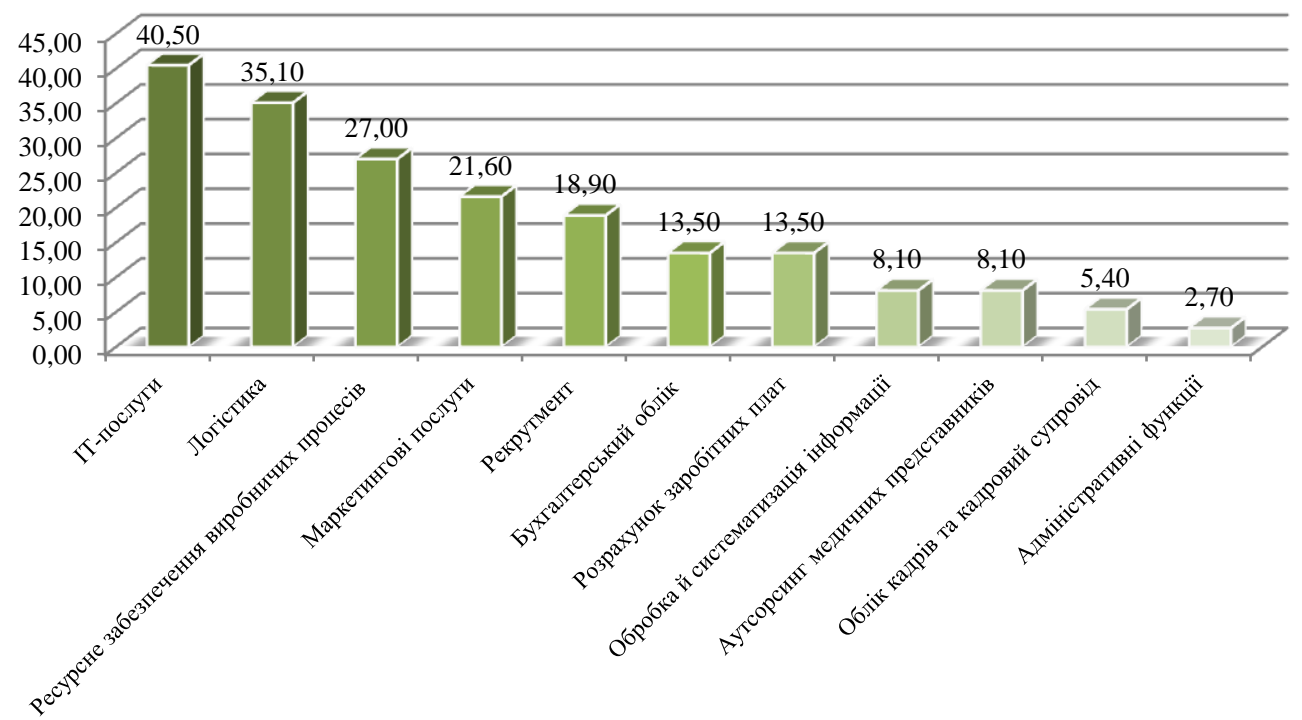

Рисунок. Видова популярність аутсорсингу в Україні, \% Складено автором на основі джерела [1] 
Аутсорсинг в Україні має ряд проблем, зокрема недостатня налагодженість зв'язків України 3 європейськими країнами, відсутність законодавчих умов для виходу іноземних підприємств на вітчизняний ринок та значний потенціал до розвитку. Незважаючи на юридичні перешкоди, зазначений сектор економіки може розвиватись значними темпами, в основному за рахунок новизни цього напряму. Найбільш перспективною $\epsilon$ ITсфера, яка наповнена прогресивними та молодими професіоналами, які готові бути гнучкими, впроваджувати нові інструменти управління та ризикувати 3 метою реалізації стратегічних цілей. Для залучення іноземних інвестицій та розвитку кадрового аутсорсингу, необхідним стає внесення поправок на законодавчому рівні та створення сприятливих умов для виходу іноземних компаній на ринок України [1].

Проте, Україна вперше потрапила в ТОП-25 найпривабливіших країн світу в сфері аутсорсингу. Україна з 2014 року піднялася із 41-го на 24-те місце в глобальному рейтингу аутсорсингової привабливості (Global Services Location Index, GSLI), що включає 55 країн - про це йдеться у звіті американської консалтингової компанії А.Т. Kearney. У дослідженні сказано, що збільшення політичних ризиків в Україні, які також впливають на позицію країни в рейтингу GSLI, було частково компенсовано за рахунок впровадження урядом реформ, які підвищили конкурентоспроможність країни.

Україна стала третьою країною за найбільшим зростанням у рейтингу після Колумбії, яка піднялась одразу на 23 позиції і посіла 20-те місце, та Туреччини, яка посіла 21-й рядок у рейтингу $(+18)$. Трійка лідерів рейтингу залишилася незмінною з 2014 року: на першому місці Індія, на другому Китай, на третьому - Малайзія. Бразилія в 2016 році піднялася на чотири позиції в рейтингу GSLI і помінялася місцями з Мексикою, яка посіла восьме місце. На п’ятому, шостому і сьомому місцях, як і раніше, залишилися Індонезія, Таїланд і Філіппіни. Замикають десятку країн-лідерів рейтингу GSLI у 2016 році Чилі, що піднялася з 13-го до дев'ятого місця, і Польща, що піднялася на одну позицію, - до 10-го місця.

A.T. Kearney складає глобальний рейтинг аутсорсингової привабливості країн GSLI кожні два роки, починаючи 3 2004-го. Аутсорсинговий потенціал кожної 3 країн оцінюється за трьома показниками: фінансової привабливості, кваліфікованості та доступності необхідних працівників на ринку праці, а також наявності сприятливого бізнес-середовища для ведення аутсорсингових операцій [8].

Проведене авторами дослідження дозволяє виділити низку характеристик та зробити порівняльний аналіз використання практики аутсорсингу в різних країнах світу у вигляді таблиці (табл. 3). 
Таблиця 3

Практики аутсорсингу в різних країнах світу

\begin{tabular}{|c|c|c|c|c|c|}
\hline № & Характеристика & США & Японія & Європа & Україна \\
\hline 1. & Рушійні сили & \multicolumn{4}{|c|}{ Зростаюча конкуренція на глобальному ринку } \\
\hline 2. & $\begin{array}{l}\text { Причини } \\
\text { переходу на } \\
\text { аутсорсинг }\end{array}$ & $\begin{array}{c}\text { Зниження } \\
\text { витрат }\end{array}$ & \multicolumn{2}{|c|}{$\begin{array}{c}\text { Підвищення ефективності } \\
\text { роботи компанії, } \\
\text { концентрація на ядрі бізнесу }\end{array}$} & Зниження витрат \\
\hline 3. & $\begin{array}{l}\text { Глибина } \\
\text { запровадження } \\
\text { аутсорсингу }\end{array}$ & \multicolumn{3}{|c|}{$\begin{array}{c}\text { Передача на аутсорсинг головних та } \\
\text { другорядних функцій, включаючи виробництво } \\
\text { та наукові розробки }\end{array}$} & 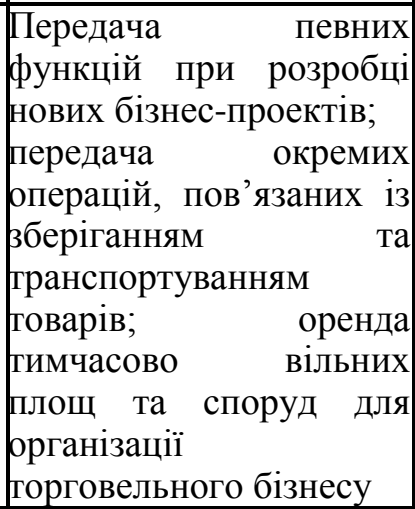 \\
\hline 4. & $\begin{array}{l}\text { Схема роботи } 3 \\
\text { провайдерами } \\
\text { аутсорсингу }\end{array}$ & Горизонтальна & Пірамідальна & Змішана & Змішана \\
\hline 5 . & $\begin{array}{l}\text { Форми } \\
\text { аутсорсингу }\end{array}$ & $\begin{array}{c}\text { Офшорний } \\
\text { (зменшення } \\
\text { частки), } \\
\text { зовнішні } \\
\text { підрядники }\end{array}$ & $\begin{array}{c}\text { Всередині } \\
\text { країни, } \\
\text { дочірні } \\
\text { підприємства } \\
\text { за кордоном }\end{array}$ & - & 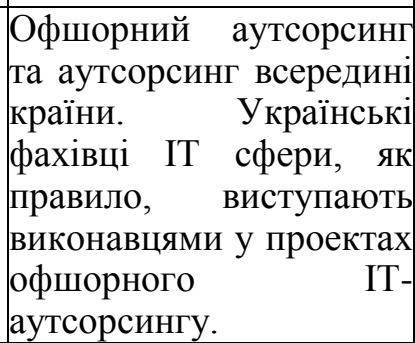 \\
\hline 6. & $\begin{array}{l}\text { Країни-виконавці } \\
\text { аутсорсингу }\end{array}$ & $\begin{array}{l}\text { Індія, Китай } \\
\quad \text { (частка } \\
\text { зменшується) }\end{array}$ & $\begin{array}{c}\text { Китай (частка } \\
\text { зростає), } \\
\text { аутсорсинг } \\
\text { всередині } \\
\text { країни }\end{array}$ & $\begin{array}{c}\text { Китай, } \\
\text { країни } \\
\text { Східної та } \\
\text { центральної } \\
\text { Свропи }\end{array}$ & $\begin{array}{l}\text { Найбільше } \text { українські } \\
\text { аутсорсери працюють } \\
\text { США - на цю країну } \\
\text { припадає } \text { близько } 80 \% \\
\text { експорту І ІТ-послуг. За } \\
\text { ними йдуть країни } \\
\text { Євросоюзу та Ізраїль }\end{array}$ \\
\hline 7. & Динаміка ринку & $\begin{array}{l}\text { Спад, } \\
\text { зменшення } \\
\text { кількості та } \\
\text { розміру угод }\end{array}$ & Стабільне зрос & ання ринку & \\
\hline 8 . & Тенденції ринку & $\begin{array}{l}\text { Переорієнтація } \\
\text { на аутсорсинг у } \\
\text { середині країни }\end{array}$ & $\begin{array}{l}\text { Стабільно } \\
\text { мала частка } \\
\text { офшорного } \\
\text { аутсорсингу, } \\
\text { орієнтація на } \\
\text { країни } \\
\text { азійського } \\
\text { регіону }\end{array}$ & $\begin{array}{l}\text { Порівняно } \\
\text { висока } \\
\text { динаміка } \\
\text { ринку за } \\
\text { рахунок } \\
\text { розвитку } \\
\text { офшорного } \\
\text { аутсорсингу } \\
\text { у країнах- } \\
\text { сусідах }\end{array}$ & $\begin{array}{lr}\text { Більшість } & \text { вітчизняних } \\
\text { компаній орієнтовані на } \\
\text { закордонні } \\
60 \% \text { ринки: } & 55- \\
\text { аутсорсингу } & \text { нашого } \\
\text { продукція на експорт }\end{array}$ \\
\hline
\end{tabular}

Складено на основі джерела [8] 
Порівняльний аналіз довів існування певних особливостей використання аутсорсингу в межах країни, або регіону. Поряд із деякими відмінними рисами для економічно розвинених країн існують певні спільні риси, пов'язані із рушійними силами, причинами використання аутсорсингу та глибиною запровадження аутсорсингу, що свідчить про розуміння економічної сутності аутсорсингу, а відтак і можливість використовувати весь його потенціал. Натомість відмінні риси свідчать про існування впливу факторів зовнішнього середовища у межах кожної країни: економічної ситуації в цілому, структури економіки, бізнес-культури, тощо [8].

Висновки. У сучасних умовах господарювання підприємства та організації задля покращення власної конкурентоспроможності на ринку за рахунок зростання рівня гнучкості виробництва, зменшення собівартості товарів і послуг та скорочення адміністративних витрат все активніше використовують новітні управлінські інструменти менеджменту, серед яких важливе місце посідає аутсорсинг. Його сутність полягає у підвищенні ефективності роботи компанії за рахунок передачі певних функцій на виконання зовнішнім організаціям з метою оптимізації всіх видів ресурсів і концентрації на основному напрямку діяльності.

Наукова новизна одержаних результатів полягає у обгрунтуванні доцільності використання зарубіжного досвіду для вітчизняних суб'єктів підприємництва задля підвищення конкурентоспроможності як окремих компаній так і України в цілому.

Теоретичне та практичне значення одержаних результатів полягає у тому, що їх впровадження дозволить вітчизняним підприємствам використовувати переваги новітнього інструменту менеджменту, аутсорсингу, у власній діяльності і залежно від специфіки роботи компанії це може бути як використання послуг вітчизняних аутсорсерів, так i закордонних спеціалізованих організацій.

Перспективи подальших наукових розробок за даним напрямом полягають у продовженні досліджень особливостей реалізації аутсорсингу за кордоном та 3 огляду на результати виокремлення пріоритетних напрямків покращення даного виду діяльності в Україні.

\section{Лiтература:}

1. Красношапка В. В., Трохимець I. I. Аутсорсинг та його застосування на підприємствах України // Ефективна економіка. - 2015. - № 5. [Електронний ресурс] Режим доступу: http://www.economy.nayka.com.ua/?op=1\&z=4097

2. Нагорна О. В. Особливості використання аутсорсингу: міжнародний досвід та вітчизняна практика/ О. В. Нагорна// Кримський економічний вісник.- 2013.- Ч.2.С.29-32.[Електронний ресурс] - Режим доступу: http://ir.kneu.edu.ua:8080/handle/2010/3483 
3. Веприцька О.А. Міжнародний аутсорсинг: переваги та ризики для компаній в країнах Південно-Східної Європи [Електронний ресурс] - Режим доступу: http://mev.khnu.km.ua/load/studentska_naukovo_praktichna_konferencija_2014/2_perspekt ivi_ta_problemi_rozvitku_mizhnarodnogo_biznesu_v_umovakh_pereformatuvannja_global nogo_sered/mizhnarodnij_autsorsing_perevagi_ta_riziki_dlja_kompanij_v_krajinakh_pivde nno_skhidnoji_evropi/54-1-0-378

4. Сівачова О. Міжнародний аутсорсинг як виклик для світової торгової системи / О. Сівачова, К. Карпова // Міжнародна економічна політика. - 2007. - № 1(6) - С.138-168 [Електронний ресурс] Режим доступу: http://iepjournal.com/journals/6/2007_06_Sivachova.pdf

5. Ковальчук Г. В. Аутсорсинг як інструмент підвищення конкурентоспроможності вітчизняних підприємств в сучасних умовах господарювання [Електронний ресурс] Режим доступу: http://www.rusnauka.com/6_NITSB_2010/Economics/59530.doc.htm

6. Кулиняк I. Я. Тенденції розвитку світового ринку аутсорсингу / I. Я. Кулиняк, О. I. Глянцева // Науковий вісник НЛТУ України. - 2014. - Вип. 24.2. - С. 259-264. [Електронний ресурс] - Режим доступу: http://nbuv.gov.ua/UJRN/nvnltu_2014_24

7. ИТ-аутсорсинг (мировой рынок)/ TAdviser/ [Електронний ресурс] - Режим доступу: http://www.tadviser.ru/index.php/

8. Микало О. І.Аналіз світового досвіду використання аутсорсингу/ О. І. Микало. // Ефективна економіка. - 2010. - № 5. [Електронний ресурс] - Режим доступу: http://www.economy.nayka.com.ua/?op=1\&z=203

9. Маленко О. Б. Роль аутсорсингу в міжнародному бізнесі [Електронний ресурс] / О. Б. Маленко // Сучасні питання економіки і права. - 2012. - Вип. 2. - С. 56-59. [Електронний ресурс] - Режим доступу: http://nbuv.gov.ua/UJRN/Spep_2012_2_10

10. Україна на першому місці в Свропі з IT-аутсорсингу [Електронний ресурс] - Режим доступу: https://www.eduget.com/news/ukraina_na_pershomu_misci_v_ievropi_z_itautsorsingu-1345

11. Мінченко О. Україна вперше потрапила в ТОП-25 найпривабливіших країн світу в сфері аутсорсингу [Електронний ресурс] - Режим доступу: http://watcher.com.ua/2016/01/13/ukrayina-vpershe-potrapyla-v-top-25-naypryvablyvishyhkrayin-svitu-v-sferi-autsorsynhu/ 